\title{
Untapped Potential of "Medical Foods" in Developed \& Developing Nations: A Mixed Method Study by a Systematic Review with Scientometric Analysis
}

\author{
Sanjeev Davey ${ }^{1}$, Anuradha Davey ${ }^{2,}$, , Jai Vir Singh ${ }^{1}$ \\ ${ }^{1}$ Community Medicine, Muzaffarnagar Medical College \& Hospital, Muzaffarnagar (Uttar Pradesh), India \\ ${ }^{2}$ Community Medicine, Subharti Medical College, Meerut (Uttar Pradesh), India
}

Email address:

Sanjeevdavey333@gmail.com (S. Davey),dranuradha.davey786@gmail.com (A. Davey), doctorjaivir@yahoo.co.in (J. V. Singh)

To cite this article:

Sanjeev Davey, Anuradha Davey, Jai Vir Singh. Untapped Potential of "Medical Foods" in Developed \& Developing Nations: A Mixed Method Study by a Systematic Review with Scientometric Analysis. International Journal of Nutrition and Food Sciences.

Vol. 4, No. 4, 2015, pp. 420-430. doi: 10.11648/j.ijnfs.20150404.12

\begin{abstract}
Background: Currently medical foods for sick and healthy persons are gaining momentum globally from its nascent stage; so it is useful to study this area, not only for patients and clinicians, but also for public health experts across the globe. Methods: Systematic review as per PRISMA (2009) guidelines on key search word: "Medical Foods" was done from all major search engines; where any kind of full text article and abstract was available till 30th September 2014 from last 40 years, later on Scientometric analysis till this search date, across developed and developing world was done. Only published data on medical foods role in any kind of disease and health physiology and health pathology available globally from both developed and developing countries was included and analyzed in our study. All sort of unpublished data as well as medical foods biochemical studies were excluded from our study. Results: Analysis of 50 articles out of 150 articles searched revealed that; Medical foods research is concentrated mainly in developed countries (e.g. USA), with very few research in context of developing countries such as India (86\% Vs 04\%). The highest number of publications were from year 2012(26\%) and belonged to English language(98\%). The Scientific research publication papers $(60 \%)$ with maximum citations between $(5-$ 10/reference) were found to be 54\%. Conclusions: Medical foods strict regulations and monitoring processes need to remain active globally, otherwise its real potential can be lost in future. Medical foods research area needs promotion in developing countries, as there is a lot of scope of its development in these nations.
\end{abstract}

Keywords: Medical Foods, FDA, Developed Nation, Developing Nation, Systematic Review, Scientometric Analysis

\section{Introduction}

Currently medical foods industry is considered as "emerging from its nascent stage"; and they are very often confused with terms such as-medical nutrition, functional foods, or nutraceuticals. ${ }^{[1]}$ The problem with this industry is that they are still not seen as a real solution to treat diseases. Infact medical foods industry is searching its space for penetration between clinical medicine and consumer nutrition.

The market of medical foods is currently prevailing at $\$ 12$ billion and the modified functional foods market are around at $\$ 26$ billion and both of them at least involve food products which provide health benefits beyond basic nutrition for the healthy general population. Key factors which are driving this industry are: a) Rapid advances in science and technology, b) increasing healthcare costs, c) changes in food labeling and claim regulations, and d)aging populations, and these factors have propelled the growth of this market. ${ }^{[2]}$ Within this upcoming industry; companies such as Abbott Labs, Nestle and Fresneius Kabi have become makers of major medical food products for diseases including Maple syrup urine disease (MSUD) and phenylketonuria (PKU), suggesting that they can be a new hope for management of such disorders. ${ }^{[2]}$

Medical food is recently defined by US FDA(2013), under section 5(b) of the Orphan Drug Act (21 U.S.C. 360ee (b) (3)) is "a food which is formulated to be consumed or administered enterally under the supervision of a physician and which is intended for the specific dietary management of a disease or condition for which distinctive nutritional requirements, based on recognized scientific principles, are established by medical evaluation". Medical foods do not 
need any premarket review or approval by FDA and they are also exempted from the labeling requirements for health claims and nutrient content claims under the Nutrition Labeling and Education Act of 1990. ${ }^{[3]}$

Medical foods are in fact specially-formulated and intended for the dietary management of a disease with distinctive nutritional needs which cannot be met by a normal diet. [3] A medical food product as per US FDA recommendation must fulfill following criteria : a) be a food for oral ingestion or tube feeding $b$ ) be labeled for the dietary management of a specific medical disorder, disease or condition for which there are distinctive nutritional requirements, and c) be intended to be used under medical supervision and they can also be classified in operating in 3 key areas such as: a) Nutritionally complete/ incomplete formulas b) Nutritional formulas for metabolic disorders, c) Nutritional formulas for Oral rehydration products. ${ }^{[3]}$

The nutritional needs in a disease state require more nutritional requirements as a main part of the medical management of clinical conditions by the use of a therapeutic product class of Medical Foods. It has now become essential to know its rapid expansion from developed to developing countries, keeping in mind that they are getting also popular in Indian set ups also due to rising health care privatization. Although Medical foods are gaining more widespread acceptance, they remain poorly understood by patients, pharmacists and physicians. The potential for medical foods is still untapped as more; more prospective, controlled studies, larger subject populations and longer treatment durations are required to unfold this area and systematic review studies and scientometric analysis are lacking in this area. This was the prime reason why authors have chosen this area for study via systematic review and scientometric analysis approach, therefore this study carries its special clinical as well as public health importance and has got greater future implications.

\section{Materials \& Methods}

First an extensive systematic review as per PRISMA(2009) guidelines on key search word: "Medical Foods" was done from all major search engines; such as Google, Pubmed, World cat, Cochrane library etc. for not only e-journals form, but also full text articles both manually and electronically were searched, where any kind of article was available till $30^{\text {th }}$ September 2014 was considered, followed later on by scientometric analysis of last 40 years. Only published data on medical foods role in any kind of disease and health physiology and health pathology available globally was included in our study and any unpublished data as well as biochemical studies on medical foods were excluded. The studies selection process as per PRISMA(2009) guidelines is explained in flow diagram given later in this paper.

Key steps followed in Scientometric-Analysis were :a) Types of studies b);Time duration of studies ,c) Primary and secondary data analysis of studies, f) Citations per year of studies, g)Analysis of language among studies, h) Citation quantities of studies.

\section{Results}

Out of 150 articles searched, 50 articles were finally considered in systematic review and scientometric analysis and these findings are explained as given below:-

\subsection{Systematic Review Findings}

Studies which were considered in systematic review after extensive searching in literature are summarized in table no: 01 given below.

Table 01. Key findings from studies considered in systematic review.

\begin{tabular}{|c|c|c|c|c|c|c|}
\hline $\begin{array}{l}\text { Name of authors or } \\
\text { institution with } \\
\text { reference citation }\end{array}$ & $\begin{array}{l}\text { Country of } \\
\text { studies }\end{array}$ & $\begin{array}{l}\text { Year of } \\
\text { studies }\end{array}$ & $\begin{array}{l}\text { Methodology-study } \\
\text { design, sample size } \\
\text { etc. }\end{array}$ & $\begin{array}{l}\text { Critical findings of } \\
\text { studies }\end{array}$ & $\begin{array}{l}\text { Main issues of } \\
\text { studies for } \\
\text { comparison }\end{array}$ & $\begin{array}{l}\text { Key issues emerged } \\
\text { from comparative } \\
\text { results }\end{array}$ \\
\hline $\begin{array}{l}\text { Thomas SM, et al }{ }^{[4]} \text {, } \\
\text { Singh } \mathrm{RH}^{[5]} \text {, Mueller } \\
\text { C. }\end{array}$ & India, USA & $\begin{array}{l}1981,1999 \\
\& 2007\end{array}$ & $\begin{array}{l}\text { Exploratory, } \\
\text { Intervention based } \\
\text { \& Descriptive } \\
\text { studies }\end{array}$ & $\begin{array}{l}\text { Sensory testing of } \\
\text { Medical foods to } \\
\text { investigate product } \\
\text { stability. } \\
\text { Regulatory history of } \\
\text { medical foods. } \\
\text { The regulatory status } \\
\text { of medical foods and } \\
\text { dietary supplements in } \\
\text { the United Sates }\end{array}$ & $\begin{array}{l}\text { Importance of } \\
\text { sensory evaluation } \\
\text { in the stability } \\
\text { testing of a medical } \\
\text { food as well as } \\
\text { timely regulation of } \\
\text { medical foods is } \\
\text { essential }\end{array}$ & $\begin{array}{l}\text { Medical Foods } \\
\text { regulation is } \\
\text { required in both } \\
\text { developed and } \\
\text { developing nations }\end{array}$ \\
\hline $\begin{array}{l}\text { International Life } \\
\text { Sciences Institute } \\
\text { Report }^{[7]} \text { Katz F }{ }^{[8]}\end{array}$ & USA & 2006,2001 & $\begin{array}{l}\text { Comprehensive } \\
\text { Review-Task Force } \\
\text { Report }\end{array}$ & $\begin{array}{l}\text { How medium chain } \\
\text { triglyceride oil has } \\
\text { been included in } \\
\text { medical foods. } \\
\text { Certain } \\
\text { microorganisms are } \\
\text { being explored for use } \\
\text { in medical foods. }\end{array}$ & $\begin{array}{l}\text { Active cultures add } \\
\text { function to yogurt } \\
\text { and other medical } \\
\text { foods, along with } \\
\text { scope of } \\
\text { microorganisms in } \\
\text { medical foods }\end{array}$ & $\begin{array}{l}\text { Medical Foods } \\
\text { Composition } \\
\text { Scenario }\end{array}$ \\
\hline Clemens R \& Pressman & USA & 2006 & Interventional & Development of & Cultured milk & Medical foods have \\
\hline
\end{tabular}




\begin{tabular}{|c|c|c|c|c|c|c|}
\hline $\begin{array}{l}\text { Name of authors or } \\
\text { institution with } \\
\text { reference citation }\end{array}$ & $\begin{array}{l}\text { Country of } \\
\text { studies }\end{array}$ & $\begin{array}{l}\text { Year of } \\
\text { studies }\end{array}$ & $\begin{array}{l}\text { Methodology-study } \\
\text { design, sample size } \\
\text { etc. }\end{array}$ & $\begin{array}{l}\text { Critical findings of } \\
\text { studies }\end{array}$ & $\begin{array}{l}\text { Main issues of } \\
\text { studies for } \\
\text { comparison }\end{array}$ & $\begin{array}{l}\text { Key issues emerged } \\
\text { from comparative } \\
\text { results }\end{array}$ \\
\hline $\mathrm{P}^{[9]}$ & & & Clinical study & $\begin{array}{l}\text { medical foods } \\
\text { provides a form of } \\
\text { dietary support for } \\
\text { patients with irritable } \\
\text { bowel syndrome (IBS) }\end{array}$ & $\begin{array}{l}\text { products enriched } \\
\text { with proprietary } \\
\text { strains of probiotic } \\
\text { organisms, which } \\
\text { are designed to help } \\
\text { regulate disordered } \\
\text { bowel function }\end{array}$ & $\begin{array}{l}\text { an important role in } \\
\text { irritable bowel } \\
\text { syndrome. }\end{array}$ \\
\hline $\begin{array}{l}\text { Shah } \mathrm{RC}^{[10]}, \text { Kamphuis } \\
\mathrm{PJ} \text {, et al }{ }^{[11],[12]} \text { Scheltens } \\
\mathrm{P}^{[36]}\end{array}$ & $\begin{array}{l}\text { India, USA, } \\
\text { Netherland }\end{array}$ & 2011 & $\begin{array}{l}\text { Descriptive and } 2 \\
\text { types of secondary } \\
\text { analyses of a } \\
\text { randomized, } \\
\text { controlled trial }\end{array}$ & $\begin{array}{l}\text { a) Medical foods can } \\
\text { play role in } \\
\text { Alzheimer's disease. } \\
\text { b) Intake adherence of } \\
\text { a medical food was } \\
\text { significantly } \\
\text { associated with higher } \\
\text { Alzheimer's Disease } \\
\text { Assessment Scale } \\
\text { cognitive scores. } \\
\text { c)baseline BMI } \\
\text { significantly } \\
\text { influences the effect of } \\
\text { Souvenaid on } \\
\text { functional abilities }\end{array}$ & $\begin{array}{l}\text { a)Opportunities for } \\
\text { medical foods in } \\
\text { treating Alzheimer's } \\
\text { disease. } \\
\text { b)Effect of a } \\
\text { medical food on } \\
\text { body mass index } \\
\text { and activities of } \\
\text { daily living in } \\
\text { patients with } \\
\text { Alzheimer's disease. }\end{array}$ & $\begin{array}{l}\text { Medical foods can } \\
\text { have an important } \\
\text { role in all stages of } \\
\text { Alzheimer's disease }\end{array}$ \\
\hline Vadillo-Ortega $\mathrm{F}$, et al ${ }^{[13]}$ & $\begin{array}{l}\text { USA, } \\
\text { Mexico }\end{array}$ & 2011 & $\begin{array}{l}\text { Randomized } \\
\text { controlled trial }\end{array}$ & $\begin{array}{l}\text { Effect of } \\
\text { supplementation } \\
\text { during pregnancy with } \\
\text { L-arginine and } \\
\text { antioxidant vitamins in } \\
\text { medical food on pre- } \\
\text { eclampsia in high risk } \\
\text { population }\end{array}$ & $\begin{array}{l}\text { Supplementation } \\
\text { during pregnancy } \\
\text { with a medical food } \\
\text { containing L- } \\
\text { arginine and } \\
\text { antioxidant vitamins } \\
\text { reduced the } \\
\text { incidence of pre- } \\
\text { eclampsia in a high- } \\
\text { risk population. }\end{array}$ & $\begin{array}{l}\text { Medical Foods can } \\
\text { have an important } \\
\text { role in reducing Pre- } \\
\text { eclampsia. }\end{array}$ \\
\hline Jones JL, et $\mathrm{al}^{[14]}$ & USA & 2011 & Randomized trial & $\begin{array}{l}\text { Addition of a } \\
\text { phytochemical-rich } \\
\text { medical food enhances } \\
\text { benefits on lipoprotein } \\
\text { metabolism }\end{array}$ & $\begin{array}{l}\text { Medical foods can } \\
\text { benefit in } \\
\text { lipoprotein- } \\
\text { metabolism. }\end{array}$ & $\begin{array}{l}\text { Medical Foods can } \\
\text { play positive role in } \\
\text { Lipoprotein } \\
\text { metabolism }\end{array}$ \\
\hline $\begin{array}{l}\text { Bentley S, et } \mathrm{al}^{[15]}, \text { Faber } \\
\mathrm{J} \text {, et } \mathrm{al}^{[16][29]}\end{array}$ & $\begin{array}{l}\text { USA \& } \\
\text { Netherlands }\end{array}$ & 2011 & $\begin{array}{l}\text { Exploratory Study-A } \\
\text { retrospective } \\
\text { analysis \& Clinical } \\
\text { Interventional Study } \\
\text { and randomized trial }\end{array}$ & $\begin{array}{l}\text { a) Supplementation } \\
\text { with a prenatal } \\
\text { medical food } \\
\text { containing L- } \\
\text { methylfolate and high- } \\
\text { dose vitamin B12 may } \\
\text { maintain hemoglobin } \\
\text { levels and reduce the } \\
\text { rates of anemia in } \\
\text { pregnancy more } \\
\text { effectively than } \\
\text { standard prenatal } \\
\text { vitamins. } \\
\text { b)Examined the } \\
\text { incorporation of EPA } \\
\text { and DHA into white } \\
\text { blood cells at different } \\
\text { time points during } 1 \\
\text { week supplementation } \\
\text { with a medical food- } \\
\text { high in protein and } \\
\text { leucine and enriched } \\
\text { with fish oil and } \\
\text { specific } \\
\text { oligosaccharides }\end{array}$ & $\begin{array}{l}\text { a)Comparative } \\
\text { effectiveness of a } \\
\text { prenatal medical } \\
\text { food to prenatal } \\
\text { vitamins on } \\
\text { hemoglobin levels } \\
\text { and adverse } \\
\text { outcomes. } \\
\text { b) The production of } \\
\text { proinflammatory } \\
\text { cytokines was } \\
\text { significantly } \\
\text { increased } \\
\text { within } 1 \text { week by } \\
\text { medical food- } \\
\text { Medical food-high } \\
\text { in protein and } \\
\text { leucine and enriched } \\
\text { with fish oil and } \\
\text { specific } \\
\text { oligosaccharides can } \\
\text { have a Positive } \\
\text { influence on WBCs. }\end{array}$ & $\begin{array}{l}\text { Medical foods can } \\
\text { be more effective } \\
\text { than vitamins in } \\
\text { Anemia and have } \\
\text { effects on WBC }\end{array}$ \\
\hline
\end{tabular}




\begin{tabular}{|c|c|c|c|c|c|c|}
\hline $\begin{array}{l}\text { Name of authors or } \\
\text { institution with } \\
\text { reference citation }\end{array}$ & $\begin{array}{l}\text { Country of } \\
\text { studies }\end{array}$ & $\begin{array}{l}\text { Year of } \\
\text { studies }\end{array}$ & $\begin{array}{l}\text { Methodology-study } \\
\text { design, sample size } \\
\text { etc. }\end{array}$ & $\begin{array}{l}\text { Critical findings of } \\
\text { studies }\end{array}$ & $\begin{array}{l}\text { Main issues of } \\
\text { studies for } \\
\text { comparison }\end{array}$ & $\begin{array}{l}\text { Key issues emerged } \\
\text { from comparative } \\
\text { results }\end{array}$ \\
\hline & & & & $\begin{array}{l}\text { Rapid EPA and DHA } \\
\text { incorporation and } \\
\text { reduced PGE2 levels } \\
\text { after one week } \\
\text { intervention with } \\
\text { a medical food in } \\
\text { cancer patients } \\
\text { receiving radiotherapy. }\end{array}$ & & \\
\hline $\begin{array}{l}\text { Deutz Nicolass EP, et } \\
\mathrm{al}^{[17]}\end{array}$ & USA & 2011 & $\begin{array}{l}\text { Randomized, } \\
\text { controlled, double- } \\
\text { blind, parallel-group } \\
\text { design }\end{array}$ & $\begin{array}{l}\text { A specially formulated } \\
\text { nutritional supplement } \\
\text { of medical food may } \\
\text { help cancer patients } \\
\text { stimulate muscle } \\
\text { protein synthesis. }\end{array}$ & $\begin{array}{l}\text { Medical foods can } \\
\text { be one option in } \\
\text { nutritional } \\
\text { supplementation of } \\
\text { Cancer patients }\end{array}$ & $\begin{array}{l}\text { Medical foods can } \\
\text { have a role in } \\
\text { Nutritional } \\
\text { supplementation of } \\
\text { Cancer patients }\end{array}$ \\
\hline $\begin{array}{l}\text { Weaver MA, et } \\
\mathrm{al}^{[18]}, \text { Berry SA etal }^{[19]}\end{array}$ & USA & 2010,2013 & $\begin{array}{l}\text { Survey of states' } \\
\text { newborn screening } \\
\text { representatives and } \\
\text { reviewed state } \\
\text { policies }\end{array}$ & $\begin{array}{l}\text { Aim to ascertain } \\
\text { payment and insurance } \\
\text { coverage of medical } \\
\text { foods. } \\
\text { Sixty-one percent of } \\
\text { states provided or } \\
\text { guaranteed medical } \\
\text { foods for all or a } \\
\text { subset of the } \\
\text { population detected by } \\
\text { the newborn } \\
\text { screening. }\end{array}$ & $\begin{array}{l}\text { Private health } \\
\text { insurance coverage } \\
\text { in } 33 \text { of } 50 \text { states } \\
\text { and states have } \\
\text { various ways of } \\
\text { defining what } \\
\text { conditions qualify } \\
\text { for medical foods. } \\
\text { Insurance coverage } \\
\text { of medical foods for } \\
\text { treatment of } \\
\text { inherited metabolic } \\
\text { disorders. Genetics } \\
\text { in Medicine is } \\
\text { needed. }\end{array}$ & $\begin{array}{l}\text { Health Insurance } \\
\text { coverage of Medical } \\
\text { foods is a debatable } \\
\text { issue. }\end{array}$ \\
\hline $\begin{array}{l}\text { Lindemann J, et } \mathrm{al}^{[20]}, \\
\text { Surette } \mathrm{ME} \text {, et } \mathrm{al}^{[21]}\end{array}$ & $\begin{array}{l}\text { USA, } \\
\text { Canada }\end{array}$ & 2009,2008 & $\begin{array}{l}\text { Clinical study } \\
\text { and } \\
\text { a randomized, } \\
\text { prospective, double- } \\
\text { blind, placebo- } \\
\text { controlled parallel } \\
\text { group trial in atopic } \\
\text { subjects with mild- } \\
\text { to-moderate asthma }\end{array}$ & $\begin{array}{l}\text { Clinical study of the } \\
\text { effects on asthma- } \\
\text { related QOL and } \\
\text { asthma management of } \\
\text { a medical food in adult } \\
\text { asthma patients. } \\
\text { The impact of a } \\
\text { medical food } \\
\text { containing } \\
\text { gammalinolenic and } \\
\text { eicosapentaenoic acids } \\
\text { on asthma } \\
\text { management and the } \\
\text { quality of life of adult } \\
\text { asthma patients. }\end{array}$ & $\begin{array}{l}\text { Medical food can } \\
\text { help to improve } \\
\text { patient perceived } \\
\text { Asthma Quality of } \\
\text { Life Questionnaire } \\
\text { Scores and improve } \\
\text { asthma management } \\
\text { through reduced } \\
\text { symptoms. } \\
\text { Self-reported asthma } \\
\text { status and } \\
\text { bronchodilator use } \\
\text { was improved in } \\
\text { subjects following a } \\
\text { regimen of medical } \\
\text { food EFF1009. }\end{array}$ & $\begin{array}{l}\text { Medical foods can } \\
\text { also play an } \\
\text { important role in } \\
\text { Asthmatic patients } \\
\text { treatment. }\end{array}$ \\
\hline $\begin{array}{l}\text { Morgan SL et al }{ }^{[22]} \text { Shell } \\
\mathrm{WE}^{[28]}\end{array}$ & USA & 2009,2012 & $\begin{array}{l}\text { Evaluation based \& } \\
\text { A double-blind } \\
\text { controlled trial }\end{array}$ & $\begin{array}{l}\text { Evaluated the safety of } \\
\text { a medical food, } \\
\text { flavocoxid, a } \\
\text { proprietary blend of } \\
\text { free-B ring flavonoids } \\
\text { and flavans from the } \\
\text { root of Scutellaria } \\
\text { baicalensis and the } \\
\text { bark of Acacia catechu } \\
\text { in the dietary } \\
\text { management of knee } \\
\text { osteoarthritis. }\end{array}$ & $\begin{array}{l}\text { Medical food with } \\
\text { flavocoxid can be } \\
\text { beneficial in knee } \\
\text { osteoarthritis. } \\
\text { A single dose } \\
\text { naproxen and an } \\
\text { amino acid medical } \\
\text { food theramine for } \\
\text { the treatment of low } \\
\text { back pain is } \\
\text { beneficial. }\end{array}$ & $\begin{array}{l}\text { Medical foods can } \\
\text { improve dietary } \\
\text { management of knee } \\
\text { osteoarthritis and } \\
\text { treatment of Low } \\
\text { back pain. }\end{array}$ \\
\hline Zaman S, et al ${ }^{[23]}$ & Pakistan & 2007 & $\begin{array}{l}\text { A placebo, } \\
\text { controlled trial }\end{array}$ & $\begin{array}{l}\text { Found B } 221 \text { reduced } \\
\text { the number of stools in } \\
\text { the acute Indiana }\end{array}$ & $\begin{array}{l}\text { B } 221 \text {, a medical } \\
\text { food containing anti- } \\
\text { secretory factor }\end{array}$ & $\begin{array}{l}\text { Medical foods can } \\
\text { be helpful in } \\
\text { managing childhood }\end{array}$ \\
\hline
\end{tabular}




\begin{tabular}{|c|c|c|c|c|c|c|}
\hline $\begin{array}{l}\text { Name of authors or } \\
\text { institution with } \\
\text { reference citation }\end{array}$ & $\begin{array}{l}\text { Country of } \\
\text { studies }\end{array}$ & $\begin{array}{l}\text { Year of } \\
\text { studies }\end{array}$ & $\begin{array}{l}\text { Methodology-study } \\
\text { design, sample size } \\
\text { etc. }\end{array}$ & $\begin{array}{l}\text { Critical findings of } \\
\text { studies }\end{array}$ & $\begin{array}{l}\text { Main issues of } \\
\text { studies for } \\
\text { comparison }\end{array}$ & $\begin{array}{l}\text { Key issues emerged } \\
\text { from comparative } \\
\text { results }\end{array}$ \\
\hline & & & & $\begin{array}{l}\text { group compared to a } \\
\text { placebo. }\end{array}$ & $\begin{array}{l}\text { reduces child } \\
\text { diarrhoea }\end{array}$ & diarrhoea \\
\hline $\begin{array}{l}\text { Morgan SL \& Baggott } \\
\mathrm{JE}^{[24]}\end{array}$ & USA & 2006 & Descriptive study & $\begin{array}{l}\text { Medical foods, } \\
\text { providing long- } \\
\text { standing and emerging } \\
\text { product examples. }\end{array}$ & $\begin{array}{l}\text { Discusses medical } \\
\text { foods, providing } \\
\text { long-standing and } \\
\text { emerging product } \\
\text { examples }\end{array}$ & $\begin{array}{l}\text { Medical foods can } \\
\text { be used in } \\
\text { management of } \\
\text { chronic diseases. }\end{array}$ \\
\hline Yannicelli S, et al. ${ }^{[25]}$ & USA & 2003 & Clinical study & $\begin{array}{l}\text { Propimex-1 improved } \\
\text { growth and nutrition } \\
\text { status in } 16 \text { patients } \\
\text { with MMA or PA } 6 \\
\text { months }\end{array}$ & $\begin{array}{l}\text { Improved growth } \\
\text { and nutrition status } \\
\text { in children with } \\
\text { methylmalonic or } \\
\text { propionic academia } \\
\text { fed an elemental } \\
\text { medical food. }\end{array}$ & $\begin{array}{l}\text { Medical foods can } \\
\text { have role in growth } \\
\text { and nutrition status } \\
\text { in children }\end{array}$ \\
\hline Heacock PM, et al. ${ }^{[26]}$ & USA & 2005 & $\begin{array}{l}\text { Double-masked, } \\
\text { randomized } \\
\text { crossover design. }\end{array}$ & $\begin{array}{l}\text { Effects of a medical } \\
\text { food containing an } \\
\text { herbal alpha- } \\
\text { glucosidase inhibitor } \\
\text { on postprandial } \\
\text { glycemia and } \\
\text { insulinemia in healthy } \\
\text { adults. }\end{array}$ & $\begin{array}{l}\text { The presence of S } \\
\text { oblonga extract } \\
\text { tended to lower } \\
\text { postprandial } \\
\text { glycemia and } \\
\text { significantly } \\
\text { reduced the } \\
\text { postprandial insulin } \\
\text { response. }\end{array}$ & $\begin{array}{l}\text { Medical foods can } \\
\text { be considered in } \\
\text { Insulin control in } \\
\text { healthy adults. }\end{array}$ \\
\hline Maxwell AJ, et al ${ }^{[27]}$ & USA & 2002 & Randomized trial & $\begin{array}{l}\text { Arginine-rich medical } \\
\text { foods in conjunction to } \\
\text { traditional therapy } \\
\text { improved vascular } \\
\text { function, exercise } \\
\text { capacity, and quality } \\
\text { of life in patients with } \\
\text { stable angina. }\end{array}$ & $\begin{array}{l}\text { Medical food for the } \\
\text { dietary management } \\
\text { of chronic, stable } \\
\text { angina }\end{array}$ & $\begin{array}{l}\text { Arginine-rich } \\
\text { medical foods can } \\
\text { be useful in patients } \\
\text { with Stable Angina. }\end{array}$ \\
\hline Shell WE et $\mathrm{al}^{[30]}$ & USA & 2012 & $\begin{array}{l}\text { Double blind, four } \\
\text { arm placebo- } \\
\text { controlled, } \\
\text { randomized trial }\end{array}$ & $\begin{array}{l}\text { Sentra PM (a Medical } \\
\text { Food) is useful along } \\
\text { with Trazodone in the } \\
\text { Management of Sleep } \\
\text { Disorders. }\end{array}$ & $\begin{array}{l}\text { Sentra PM can } \\
\text { improve the quality } \\
\text { of sleep, the } \\
\text { response to } \\
\text { trazodone as a sleep } \\
\text { medication and } \\
\text { parasympathetic } \\
\text { autonomic nervous } \\
\text { system activity. }\end{array}$ & $\begin{array}{l}\text { Medical Foods are } \\
\text { useful in the } \\
\text { Management of } \\
\text { Sleep Disorders. }\end{array}$ \\
\hline
\end{tabular}

\subsection{Scientometric-Analysis Findings}

a) Global research output in Medical foods:

The oldest medical foods publications published work was published in 1981 and the latest was in year 2014. b) Global country wide analysis:

The majority of medical foods research articles were concentrated in developed country such as USA(86\%) as shown below in table no 2 as given below.

Table 02. Country wise distribution of Medical foods publication.

\begin{tabular}{llll}
\hline S.No & Country of research articles & $\begin{array}{l}\text { No of Publications contributed for medical foods } \\
\text { research }(\mathbf{n}=\mathbf{5 0})\end{array}$ & $\begin{array}{l}\text { \% of Publications contributed for medical foods } \\
\text { research }\end{array}$ \\
\hline 1 & USA & 43 & 86 \\
2 & Netherlands & 2 & 4 \\
3 & India & 2 & 4 \\
4 & Pakistan & 1 & 2 \\
5 & Mexico & 1 & 2 \\
6 & Canada & 1 & 2 \\
& Total & 50 & 100 \\
\hline
\end{tabular}


c) Language wise analysis of publications:

The majority of published papers were belonged to English language $(98 \%)$ as shown below in table no3 given below.

Table 03. Language wise analysis of publications.

\begin{tabular}{llll}
\hline S.No & $\begin{array}{l}\text { Language of } \\
\text { Publication }\end{array}$ & $\begin{array}{l}\text { No of Publications } \\
(\mathbf{n = 5 0})\end{array}$ & $\begin{array}{l}\text { \% of } \\
\text { Publications }\end{array}$ \\
\hline 1 & English & 49 & 98 \\
2 & Dutch & 1 & 2 \\
& Total & 50 & 100 \\
\hline
\end{tabular}

d) Publication type- Categories of Journals found:

5 major categories of journals were found out of 50 articles:

1. Journal of Food Science Research Articles- Total -1

2. Comprehensive Reviews in Food Science and Food Safety- Total -2

3. Food Technology Magazine Articles Total -4

4. Other Scientific Publications papers Total -30
5. Articles from websites and other journals-13

The maximum contribution in medical foods research globally was maximum from Scientific Publication Papers $(60 \%)$.

e) Year wise analysis:

The year wise analysis reveals that only from 2010 onwards; the real potential of medical foods have been recognized, giving rise to spurt of publications in year 2011(16\% ), 2012(26\%),2013(18\%) and decades of 80s and $90 \mathrm{~s}$ had practically no research output, on analyzing data from 1980 to 2014.

f) Citations Analysis:

The citation analysis of medical foods published articles reveals that maximum citations were between 5-10 citations of references considered in scientometric analysis (54\%) for major indexing agencies such as Pubmed as shown in table no: 04 given below.

Table 04. Citation analysis of Medical Foods publications.

\begin{tabular}{|c|c|c|c|}
\hline $\begin{array}{l}\text { Ref no. of publication considered in } \\
\text { scientometric analysis }\end{array}$ & $\begin{array}{l}\text { No of citations category of Ref } \\
\text { no of papers }\end{array}$ & $\begin{array}{l}\text { Total no of citations of references in } \\
\text { major indexing agencies }(n=50)\end{array}$ & $\begin{array}{l}\% \text { citations of references in } \\
\text { major indexing agencies }\end{array}$ \\
\hline $1-3,41-50$ & $<5$ citations & 13 & 26 \\
\hline $4-30$ & $10-15$ citations & 10 & 20 \\
\hline $31-40$ & 5-10 citations & 27 & 54 \\
\hline Total & & 50 & 100 \\
\hline
\end{tabular}

\section{Discussion}

Medical foods are cheaper than most drugs available at the counter; but they must be used in conjunction with pharmaceuticals and only under the supervision or direction of a physician to treat the particular ailment under a doctor's guidance for any specific nutritional deficiency of a disease. Moreover alone they should not be used to treat, cure, prevent, mitigate as they do not have a direct impact on disease in a manner similar to drugs or other medical treatments. The Systematic review followed by scientometric analysis revealed following thematic issues from our study as described below:

Theme: 01: Medical Foods regulation requirement in developed and developing nations

The term "medical foods" does not pertain to all foods fed to sick patients. Medical foods can support nutrition above normal consumption levels to induce beneficial physiological health effects through the use of bioactive compounds. Medical foods are used to support the dietary management of a disease with an aim to minimize disease symptoms and reduce disease progression for a specific group of individuals. Medical foods however must be used only under medical supervision. ${ }^{[1-3]}$ Medical foods cannot make therapeutic claims for treating; preventing or mitigating specific diseases like drugs can, but, they can go beyond the structure/function claims of supplements to make medical claims for dietary management of a specific disease. Although these foods are covered under the Worker's Compensation Insurance plans and Medicare Part D, but health insurance have not yet completely covered them. ${ }^{[1-3]}$

Many studies such as that of Thomas SM, et al ${ }^{[4]}$, Singh $\mathrm{RH}^{[5\}}$, Mueller $\mathrm{C}^{[6]}$ have also emphasized on this issue as found in our systematic review. It has become evident that Medical foods can be used in a wide variety of acute and chronic diseases despite regulatory issues globally. Our scientometric findings indicated that- the majority of studies on medical foods have been done in developed nations such as USA with less research in developing countries such as India. The highest number of publications was published in year 2012(26\%). Starting from 2011 there was a dramatic increase in the number of published items.

\section{Theme: 02- Medical Foods Composition Scenario}

The study of International Life Sciences Institute Report ${ }^{[7]}$ Katz $\mathrm{F}^{[8]}$ has indicated that Medical foods are different from drugs or supplements as found in our systematic review. Medical foods are primarily formulated for specific disease populations, whereas supplements are intended for healthy adults and further there are differences among medical foods, drugs and dietary supplements. ${ }^{[1-3]}$

Theme: 03-Global scenario of role of medical foods among various Diseases and Physiological states

Our systematic review \& scientometric analysis indicates that the medical foods can have a role in both diseases as well as physiological health conditions. Emerging diseases such as osteoporosis or osteopenia, insomnia and heart disease etc are associated with metabolic imbalances and these patients have specific nutritional requirements in treatment, here medical foods can be an answer. But Medical foods sensory regulation as well coverage by health insurance companies is an area where controversies needs to 
be solved on urgent basis, as medical foods are also exhibiting good benefits despite limitations. ${ }^{[4-8]}$ Our systematic-review have shown effectiveness of specific kinds of medical foods in diseases such as Diarrhoea, Irritable Bowel Syndrome, Stable Angina, Anemia, Alzheimer's disease, Asthmatic patients, knee osteo-arthritis, many chronic diseases, and even in pre-eclampsia patients. ${ }^{[9-13,15,18-}$ 24,27-29,34,36-38] The medical foods are now even found to be useful in nutritional status maintenance in children, Insulin control in healthy adults, sleep disorders. ${ }^{[14,16-17,25-26,30,30-33,39-}$ ${ }^{40]}$ as found in our systematic review.

The medical foods creation with greater health benefits for a particular patient is a complex process; so a better understanding of the development, substantiation, and commercialization of a medical food is necessary in nutrition therapy for the critically ill patients[Ochoa JB et al (2011)]. ${ }^{[31]}$ Few medical foods may have some negative effects such as Flavocoxid, as it can cause clinically significant liver injury, but this may resolve within weeks after cessation as found in study of Chalasani N (2012). ${ }^{[32]}$ But no doubt Medical foods are shown to be effective in rare diseases such as fibromyalgia; as it was found that a program consisting of a phytonutrient-rich medical food and an elimination diet ameliorated fibromyalgia symptoms and promoted toxicelement detoxification, suggesting their role in management of fibromyalgia patients [Lamb J J et al(2011)]. ${ }^{\text {[33] }}$

The medical food (Theramine) is found to be effective in relieving back pain without causing any significant side effects and it can be a safe alternative to current therapies. ${ }^{[28]}$

\section{Theme: 04-Emerging roles of medical foods in common disorders}

Our scientometric analysis revealed that; as the majority of published papers belonged to English language(98\%), so there is an upcoming emerging roles of medical foods in common disorders in both developed and developing nations, as revealed by our systematic-review. Medical foods now even have a great scope in management of common disorders such as diarrhea. The efficacy and tolerability of a tannic acid-based medical food, Cesinex was found to be very promising in the treatment of diarrhea, in study by Ren A(2012). ${ }^{[34]}$ Supplementation with the proper balance of omega- 3 and omega- 6 essential fatty acids medical food was also found to improve and relieve patients dry eye symptoms in study by Jackson MA(2011). ${ }^{[35]}$

Even supplemental medical food program by Medical foods can provide an important adjunctive therapy for the management of many complex symptoms associated with the chronic health problems as found in study by Bland JS(1995). ${ }^{[37]}$ Many Dietary supplements, medical foods, and pharmaceutical agents are now increasingly used in the management of metabolic bone disease such as osteopenia and osteoporosis as per the study of Morgan SL(2013). ${ }^{[38]}$

Our systematic review also found that medical foods actually require global nutravigilance. Nutravigilance is the "the science and activities relating to the detection, assessment, understanding and prevention of adverse effects related to the use of a food, dietary supplement, or medical food". ${ }^{[3]}$ All ingredients of medical foods must also be GRAS (generally recognized as safe) or approved food additives. While many more fortified-food ingredients have achieved GRAS status, it is not required for those products. "A medical food by definition must contain GRAS ingredients, and this status is not given easily and widely to all so-called natural ingredients. So what is required is better scrutiny of the efficacy of medical foods. ${ }^{[40]}$

Theme: 05- Global scenario of Medical Foods Industry

Our scientometric analysis also revealed that Medical foods area has been very little researched in food sciences $(2 \%)$ area indicating its link with industrial inclination. The medical foods industry itself in developed and developing world is ill-defined; but relatively lightly regulated by the Food and Drug Administration (FDA) and within the rules, a medical food company can market its product for use in managing specific diseases without falling under FDA's more stringent drug requirements. Market for medical nutrition globally is now therefore expanding at a rapid rate, as in 2013 it was around US\$29 billion; and with CAGR of 5.8\%, it is expected to reach US $\$ 40.1$ billion by $2018 .^{[3]}$

Currently, marketed medical foods with a wide variety of claims are used extensively as a life support modality in the management of the critically ill and elderly. The use of medical foods although appearing to be necessity to treat inherited metabolic disorders, but it is still even not covered by medical insurance companies. They are required to conform only to those regulations dealing with general food safety and labeling to be distributed in the United States. ${ }^{[4-8,}$ ${ }^{41]}$ As the U.S. population is more graying and more elderly people often go to hospitals, nursing homes or lose the ability to eat or metabolize food normally as well as the barriers to market entry are lower than for other medical products, therefore the need for medical foods is expected to continue to grow globally.

Our scientometric analysis also revealed that maximum citations were between 5-10 citations of references considered in scientometric analysis (54\%) for major indexing agencies such as Pubmed indicating the importance of this subject in scientific literature.

Theme: 06-Medical Foods industry scenario in developing nations: Indian example

The Scarcity of medical foods research articles from developing countries such as Netherland(4\%),India(4\%) Mexico, Pakistan(2\% each respectively) as found in scientometric analysis also indicates; despite being potential of medical foods in many diseases and physiological states, as indicated also by our systematic review suggests that, medical foods yet to become popular in developing nations.

Medical foods are now in great demand not only globally, but also in Indian markets, as compared to traditional medical nutrition products. In fact they are unfolding the barriers for a new market dominated by very few players. However, this industry is still in a budding stage in India and can grow a lot in future. Indian medical foods market revenues is expected to go upto USD 4.2 billion in $2017 .{ }^{[42]}$ Between "drugs, medicines \& nutritional supplements" prevails a very thin 
line(Dalmia VP 2013) and Present Indian law for foods is defined in the (Indian) FOOD SAFETY AND STANDARDS ACT, 2006, (FSS Act ) under which an embargo has been placed under Section 22 of the FSS Act, indicating that medical foods have a scope of its expansion in India. ${ }^{[43]}$

\section{Global Examples of Key Medical Foods Composition in Diseases: Useful for Developed \& Developing World ${ }^{[44-50]}$}

\subsection{Allergic-Disorders Treatment}

They contain both gamma-linolenic acid (GLA) and eicosapentaenoic acid (EPA).

\subsection{Diabetes Mellitus Treatment}

Medical foods for management of diabetes mellitus contain slowly digested carbohydrates, which helps minimize peaks in blood sugar.

\subsection{Gastrointestinal Tract Diseases Treatment}

They provide an amino acid-based diet in its most easily digestible elemental form to aid in poor nutrient absorption due to digestive disease, malabsorption, severe food allergies etc.

\subsection{Metabolic Stress Relief Treatment}

Medical foods provide supplemental glutamine to nourish the GI tract and restore glutamine when a patient is in a stressed, catabolic state.

\subsection{Chronic Pain Treatment}

Increased nutritional deficiencies associated with chronic idiopathic pain have been found to have documented deficiencies in tryptophan, histidine, serine and arginine. Medical foods such as Theramine - specifically formulated to manage the pain and inflammation of specific disease states, are specifically formulated to meet the distinctive nutritional requirements of a specific disease that cannot be met with a simple dietary shift.

Newer areas to boost Medical foods industry in future:

Focusing on areas such as- increasing yield response of common foods such as Rice which requires interplay of biophysical, socio-economic and structural forces for better creation of medical foods [Boansi D et al(2014)] ${ }^{[51]}$ and integrating better fertilization management practices are some of the options in increasing and sustaining foods (rice) production[Issaka $\mathrm{RN}$ et al 2014] ${ }^{[52]}$.

\subsection{Limitations of Study}

In our study PRISMA guidelines were followed only up to systematic review step and thereafter study was completed by way of a scientometric analysis approach. All steps of scientometric analysis could not be followed in study due to inclusion criteria taken, so this may be a limiting issue in the number of studies and type of analysis considered in scientometric analysis.

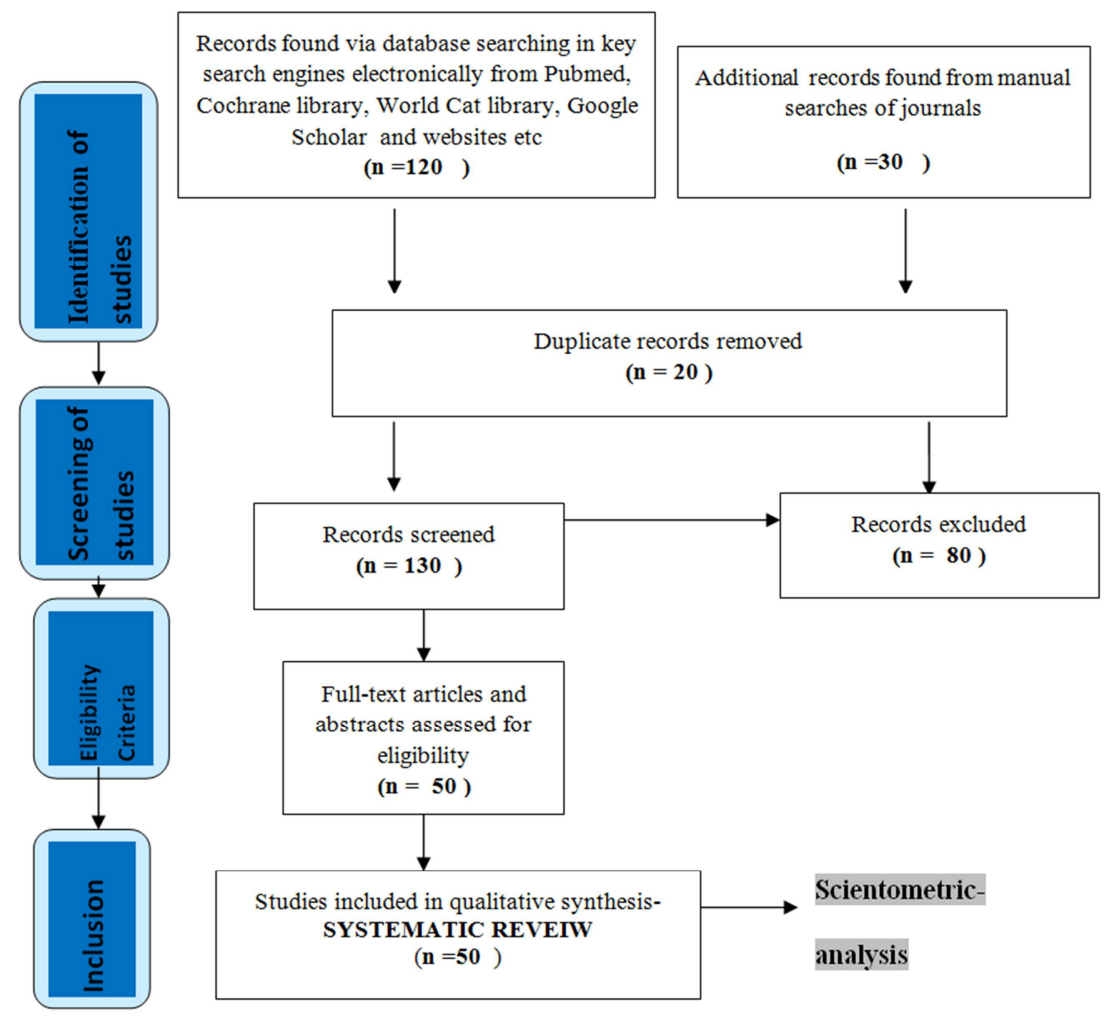

Flow diagram: Studies selection process in Systematic review and Scientometric analysis 


\section{Conclusions}

Both market and industry of medical foods is expanding rapidly in both developed and developing nations such as India to include medical food products with an increase in patenting activity. Medical foods can help in diseases such as type 2 diabetes, metabolic syndromes, chronic fatigue syndrome etc apart from common diseases such as diarrhea. The medical nutrition market in India due to medical foods entry can also grow tremendously in the next five years, but what is required is ongoing regulatory and monitoring actions to get its utility to fullest. Authors therefore suggest that further exploratory and meta-analysis studies can be carried out in future in this field on priority basis, to have a more precise estimation of its global future impact on health of patients and individuals.

\section{References}

[1] Gauhier B \& Yeow A. Medical Foods in the Middle. Available from: http:/www.skimgroup.com/publication-medical-foodsnbj. [Last updated 2014, Jan 1; Last cited 2014 April 14]

[2] New Business Opportunities Identified in Rapidly Growing \$38 Billion Medical and Functional Foods Markets. Available from:http://www.prnewswire.com/news-releases/newbusiness-opportunities-identified-in-rapidly-growing-38billion-medical-and-functional-foods-markets216440021.html. [Last updated 2014, March 31; Last cited 2014 March 31].

[3] Medical Foods Guidance Documents \& Regulatory Information. [Internetc2013] Available from:http://www.fda.gov/Food/GuidanceRegulation/Guidance DocumentsRegulatoryInformation/MedicalFoods/default.html. [Last updated 2013, Aug 21; Last cited 2014 March 26].

[4] Thomas SM, F. CAPORASO,G.A. MILLER and R.M. KIRAL. Importance of sensory evaluation in the stability testing of a medical food. J Food Sci 1981;46(2):435-439.

[5] Singh RH. The enigma medical foods. Molecular Genetics \& Metabolism 2007;92(1-2):3-5.

[6] Mueller C. The regulatory status of medical foods and dietary supplements in the United Sates. Nutrition 1999;15(3):249251.

[7] Task Force of the ILSI International Food Biotechnology Committee. Comp Rev Food Sci \& Food Safety 2004;3:38104.

[8] Katz F. Active cultures add function to yogurt and other foods. Food Tech 2001;55(3).

[9] Clemens R \& Pressman P. Medical foods and irritable bowel syndrome. Food Tech 2006;60(8).

[10] Shah RC. Medical foods for Alzheimer's Disease. Drugs Aging 2011;28(6);421-428.

[11] Kamphuis PJ, Verhey FR, Olde Rikkert MG, Twisk JW, Swinkels SH, Scheltens P. Efficacy of a medical food on cognition in Alzheimer's disease: Results from secondary analyses of a randomized, controlled trial. J Nutr Health Aging 2011;15(8):720-724.

[12] Kamphuis PJ, Verhey FR, Olde Rikkert MG, Twisk JW, Swinkels SH, Scheltens P. Effect of a medical food on body mass index and activities of daily living in patients with Alzheimer's disease: Secondary analyses from a randomized, controlled trial. J Nutr \& Aging 2011;15(8):672-676.

[13] Vadillo-Ortega F, Perichart-Perera O, Espino S, Avila-Vergara MA, Ibarra I, Ahued R, Godines M, Parry S, Macones G,Strauss JF. Effect of supplementation during pregnancy with L-arginine and antioxidant vitamins in medical food on pre-eclampsia in high risk population: Randomized controlled trial. BMJ 2011;342:d2901.

[14] Jones JL,Fernandez ML, McIntosh MS, Najm W, Calle MC, Kalynych C, Vukich C, Barona J, Ackermann D, Kim JE,Kumar V, Lott M, Volek JS, Lerman RH. A Mediterraneanstyle low-glycemic-load diet improves variables of metabolic syndrome in women, and addition of a phytochemical-rich medical food enhances benefits on lipoprotein metabolism. J Clin Lipidol 2011;5(3):188-196.

[15] Bentley S, Hermes A, Phillips D, Daoud YA, Hanna S. Comparative effectiveness of a prenatal medical food to prenatal vitamins on hemoglobin levels and adverse outcomes: A retrospective analysis. Clin Ther 2011;33(2):204-210.

[16] Faber J, Berkhout M, Vos AP, Sijben JW, Calder PC, Garssen J, van Helvoort A. Supplementation with a fish oil-enriched, high-protein medical food leads to rapid incorporation of EPA into white blood cells and modulates immune responses within one week in healthy men and women. J Nutr 2011;141(5):Epub 2011.

[17] Deutz Nicolass EP, Safar A, Schutzler S, Memelink R, Ferrando A, Spencer H, van Helvoort A, Wolfe RR. Muscle protein synthesis in cancer patients can be submitted with a specially formulated medical food. Clin Nutr 2011;30(6):759768

[18] Weaver MA, Johnson A, Singh RH, Wilcox WR, LloydPuryear MA, Watson MS. Medical foods: Inborn errors of metabolism and the reimbursement dilemma. Genet Med 2010;12(6):364-369.

[19] Berry SA ,Kenney KM , Harris kB, Singh RH , Cynthia A. Cameron , Jennifer N. Kraszewski et al. Insurance coverage of medical foods for treatment of inherited metabolic disorders. Genetics in Medicine 2013;15,978-982.

[20] Lindemann J, David Pampe E, Peterkin JJ, Orozco-Cronin P, Belofsky G, Stull D. Clinical study of the effects on asthmarelated QOL and asthma management of a medical food in adult asthma patients. Curr Med Res Opin 2009;25(12):28652875 .

[21] Surette ME, Stull D, Lindemann J. The impact of a medical food containing gammalinolenic and eicosapentaenoic acids on asthma management and the quality of life of adult asthma patients. Curr Med Res Opin 2008;24(2):559-567.

[22] Morgan SL, Baggott JE, Moreland L, Desmond R, Kendrach AC. The safety of flavocoxid, a medical food, in the dietary management of knee osteoarthritis. J Med Food 2009;12(5):1143-1148. 
[23] Zaman S, Mannan J, Lange S, Lönnroth I, Hanson LA. B 221, a medical food containing antisecretory factor reduces child diarrhoea: A placebo, controlled trial. Acta Paediatr 2007;96(11):1655-1659.

[24] Morgan SL \& Baggott JE. Medical foods: Products for management of chronic diseases. Nutr Rev 2006;64(11):495501.

[25] Yannicelli S, Acosta PB, Velazquez A, Bock HG, Marriage B, Kurczynski TW, Miller M, Korson M, Steiner RD, Rutledge L, Bernstein L, Chinsky J, Galvin-Parton P, Arnold GL. Improved growth and nutrition status in children with methylmalonic or propionic academia fed an elemental medical food. Molecular Genetics \& Metabolism 2003; 80(1-2):181-188.

[26] Heacock PM, Hertzler SR, Williams JA, Wolf BW. Effects of a medical food containing an herbal alpha-glucosidase inhibitor on postprandial glycemia and insulinemia in healthy adults. J Am Diet Assoc 2005; 105(1):65-71.

[27] Maxwell AJ, Zapien MP, Pearce GL, MacCallum G, Stone PH. Randomized trial of a medical food for the dietary management of chronic, stable angina. J Am Coll Cardiology 2002;39(1):37-45.

[28] Shell WE, Charuvastra EH, DeWood MA, May LA, Bullias DH, Silver DS. A double-blind controlled trial of a single dose naproxen and an amino acid medical food theramine for the treatment of low back pain. Am J Ther 2012 Mar;19(2):108-14.

[29] Faber J, Berkhout M, Fiedler U, Avlar M, Witteman BJ, Vos AP, Henke M, Garssen J, van Helvoort A, Otten MH, Arends J.Rapid EPA and DHA incorporation and reduced PGE2 levels after one week intervention with a medical food in cancer patients receiving radiotherapy, a randomized trial. Clin Nutr 2013 Jun;32(3):338-45. doi: 10.1016/j.clnu.2012.09.009. Epub 2012 Sep 28.

[30] Shell WE, May LA, Bullias DH, Pavlik SL, Silver DS.Sentra PM (a Medical Food) and Trazodone in the Management of Sleep Disorders. J Cent Nerv Syst Dis 2012 Apr 23;4:65-72.

[31] Ochoa JB, McClave SA, Saavedra J.Issues involved in the process of developing a medical food. JPEN J Parenter Enteral Nutr 2011 Sep;35(5 Suppl):73S-9S.

[32] Chalasani N, Vuppalanchi R, Navarro V, Fontana R, Bonkovsky H, Barnhart H, Kleiner DE, Hoofnagle JH.Acute liver injury due to flavocoxid (Limbrel), a medical food for osteoarthritis: a case series. Ann Intern Med 2012 Jun 19;156(12):857-60, W297-300.

[33] Lamb JJ, Konda VR, Quig DW, Desai A, Minich DM, Bouillon L, Chang JL, Hsi A, Lerman RH, Kornberg J, Bland JS,Tripp ML. A program consisting of a phytonutrient-rich medical food and an elimination diet ameliorated fibromyalgia symptoms and promoted toxic-element detoxification in a pilot trial. Altern Ther Health Med 2011 Mar-Apr;17(2):36-44.

[34] Ren A, Zhang W, Thomas HG, Barish A, Berry S, Kiel JS, Naren AP.A tannic acid-based medical food, Cesinex( $(\mathbb{R})$, exhibits broad-spectrum antidiarrheal properties: a mechanistic and clinical study. Dig Dis Sci 2012 Jan;57(1):99108. Epub 2011 Jul 12.

[35] Jackson MA, Burrell K, Gaddie IB, Richardson SD. Efficacy of a new prescription-only medical food supplement in alleviating signs and symptoms of dry eye, with or without concomitant cyclosporine A. Clin Ophthalmol 2011;5:1201-6. Epub 2011 Aug 25.
[36] Scheltens P, Kamphuis PJ, Verhey FR, Olde Rikkert MG, Wurtman RJ, Wilkinson D, Twisk JW, Kurz A. Efficacy of a medical food in mild Alzheimer's disease: A randomized, controlled trial. Alzheimers Dement 2010 Jan;6(1):1-10.e1.

[37] Bland JS, Barrager E, Reedy RG, Bland K.A Medical FoodSupplemented Detoxification Program in the Management of Chronic Health Problems. Altern Ther Health Med 1995 Nov $1 ; 1(5): 62-71$.

[38] Morgan SL. Dietary supplements and medical foods for osteopenia and osteoporosis. J Clin Densitom 2013 OctDec;16(4):394-401.Epub 2013 Oct 4.

[39] Schmitz SM, Lopez HL, MacKay D. Nutravigilance: principles and practices to enhance adverse event reporting in the dietary supplement and natural products industry. Int J Food Sci Nutr 2014 Mar;65(2):129-34.Epub 2013 Oct 11.

[40] Katan MB.[Health claims for medical foods.[Article in Dutch] Ned Tijdschr Geneeskd 2013;157(24):A6471.

[41] US food and drug administration compliance program guidance manual. chapter 21 - food composition, standards, labeling and economics.2008;sep 30:1-30

[42] The Medical Nutrition Market in India is Expected to Grow Tremendously in the Next Five Years. Available from: http://www.prnewswire.co.in/news-releases/the-medicalnutrition-market-in-india-is-expected-to-grow-tremendouslyin-the-next-five-years-226692811.html.[Last updated 2013, Oct 7; Last cited 2014 March 25].

[43] Dalmia,VP. India: Law Of Nutritional \& Supplemental Food Products In India - The Conflict: Food Or Drug?[Internetc2014] Available from: http://www.mondaq.com/india/x/221116/food+drugs+law/La $\mathrm{w}+$ Of+Nutritional+Supplemental+Food+Products+In+India. [Last updated 2013, Feb 12; Last cited 2014 April 2].

[44] About-axona.com. Available from: http://www.aboutaxona.com/ [Last updated 2013, May 02; Last cited 2014 April 30].

[45] "Banatrol Plus". Available from: http://www.medtrition.com/banatrol-diarrhea-relief/. [Last updated 2013, Aug 30; Last cited 2014 April 30].

[46] "Deplin ${ }^{\circledR}$ (L-methylfolate) | Official Site". Available from: http://www.deplin.com/ [Last updated 2013, June 3; Last cited 2014 April 30].

[47] "Fosteum PLUS - The Purity of Genistein with the Strength of Calcium". Available from: http://www.fosteumplus.com/ [Last updated 2013, May 31; Last cited 2014 April 30].

[48] "Osteoarthritis Information - Knee Osteoarthritis Symptoms". Limbrel. Available from: http://www.limbrel.com/osteoarthritis-symptoms.php Retrieved 2013-08-30. [Last updated 2013, Aug 30; Last cited 2014 April 30].

[49] "Home"- Metanx.com. Available from: http://www.metanx.com/ 2013-01-24. [Last updated 2013, Aug 30; Last cited 2014 April 30].

[50] American-therapeutics(theramine).Available From : http://journals.lww.com/americantherapeutics/pages/results.as px?txtKeywords=theramine. [Last updated 2013, Aug 30; Last cited 2014 April 30]. 
[51] David Boansi, Yield Response of Rice in Nigeria: A CoIntegration Analysis, American Journal of Agriculture and Forestry $2014 ; 2(2): 15-24$

[52] Roland Nuhu Issaka, Moro Mohammed Buri, Satoshi
Nakamura, Satoshi Tobita, Comparison of Different Fertilizer Management Practices on Rice Growth and Yield in the Ashanti Region of Ghana. Agriculture, Forestry and Fisheries. 2014; 3(5):374-379. 